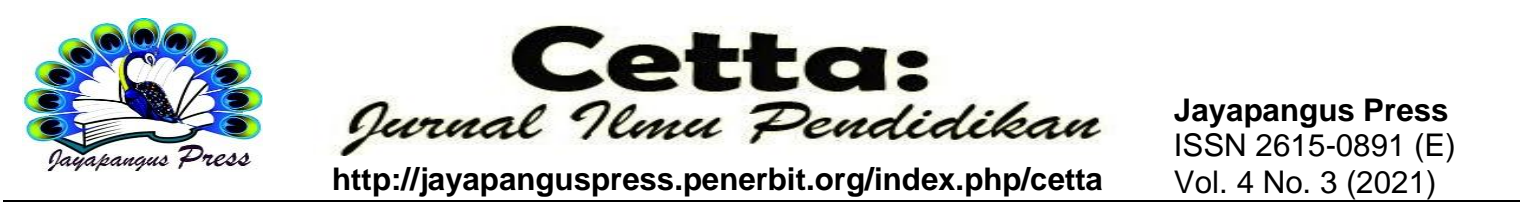

\title{
Melalui Pembelajaran Metode Bermain Peran Untuk Meningkatkan Aktivitas dan Hasil Belajar IPA Pada Siswa Kelas VI SDN 1 Seraya Barat
}

I Komang Suryasa

SD Negeri 1 Seraya Barat

suryasakomang76@gmail.com

\begin{tabular}{l}
\hline Keywords: \\
\hline Improving; Role \\
Playing; \\
Activities; \\
Learning \\
Outcomes \\
\hline
\end{tabular}

Abstract
The implementation of good learning cannot be separated from
the learning process which consists of interactions between
teachers and students in exploring teaching materials and media.
The problem is whether the implementation of learning using the
role-playing method can improve science learning activities and
outcomes in class VI students in semester I at SDN 1 Seraya
Barat for the $2019 / 2020$ academic year? The subjects of this
study were students of Class VI Semester I SDN 1 West Seraya
with a total of 27 people. For the purposes of data collection,
observation methods and measurement sheets were used. The
data obtained were analyzed using descriptive qualitative
analysis techniques. Based on the data analysis, it can be
concluded that the Role Playing Method can improve the
activities and learning outcomes of science subjects. This is
evidenced by the increase in science learning activities for Class
VI students in Semester I at SDN 1 Seraya Barat with the average
activity value increasing from 73.46 in the first cycle to 84.57 in
the second cycle and the average learning outcome from 69.55
in the first cycle to 85.80 in the second cycle with the second
cycle activity completeness 85.19\% and the second cycle
learning outcomes $88.89 \%$. From the results of the Classroom
Action Research, researchers will continue similar activities to
improve the quality of learning in schools.

Kata Kunci:

Abstrak

Meningkatkan;

Bermain Peran;

Aktifitas; Hasil

Pelaksanaan pembelajaran yang baik tidak lepas dari proses pembelajaran yang terdiri dari interaksi antara guru dan siswa dalam mengeksplorasi materi dan media ajar. Permasalahan apakah pelaksanaan pembelajaran dengan metode Bermain Peran dapat Meningkatkan Aktivitas dan Hasil Belajar IPA Pada Siswa Kelas VI Semester I Di SDN 1 Seraya Barat Tahun Pelajaran 2019/2020? Subyek penelitian ini adalah siswa Kelas VI Semester I SDN 1 Seraya Barat dengan jumlah 27 orang. Untuk keperluan pengumpulan data dipergunakan metode observasi dan lembar pengukuran. Data yang diperoleh dianalisis dengan menggunakan teknik analisis kualitatif 
deskriptif. Berdasarkan analisis data dapat disimpulkan bahwa Metode Bermain Peran dapat meningkatkan aktifitas dan hasil belajar mata pelajaran IPA . Hal ini terbukti dengan meningkatnya aktifitas pembelajaran IPA siswa Kelas VI Semester I di SDN 1 Seraya Barat dengan rerata nilai aktifitas meningkat 73,46 pada siklus I menjadi 84,57 pada siklus II dan rerata hasil belajar dari 69,55 pada siklus I menjadi 85,80 pada siklus II dengan ketuntasan aktivitas siklus II 85,19\% dan hasil belajar siklus II 88,89\%.Dari hasil Penelitian Tindakan Kelas tersebut, peneliti akan melanjutkan kegiatan sejenis untuk meningkatkan kualitas pembelajaran di sekolah.

\section{Pendahuluan}

Pelaksanaan pembelajaran yang baik tidak lepas dari proses pembelajaran yang terdiri dari interaksi antara guru dan siswa dalam mengeksplorasi materi dan media belajar. Peran guru sebagai fasilitator pembelajaran sangat menentukan keberhasilan pembelajaran dari sisi penerapan strategi dan penggunaan media belajar. Sementara peran siswa sebagai pebelajar ikut menentukan keberhasilan pembelajaran dari sisi tingkat aktivitas dan keterlibatan dalam proses pembelajaran tersebut. Selama peneliti sebagai guru sering kali menemukan hasil belajar siswa yang rendah yang di tandai dengan daya serap belajar siswa yang rendah. Hal ini penulis temukan di antaranya pada hasil ulangan IPA sebelumnya. Data menunjukan tingkat penguasaan materi IPA $50 \%$ dengan tingkat ketuntasan $20 \%$.

Pembicaraan dengan pengawas dan rekan-rekan guru diketahui bahwa faktor penyebab siswa kurang mampu menguasai materi yang diajarkan adalah kurangnya perhatian siswa ketika pembelajaran berlangsung atau saat guru, menjelaskan \penjelasan guru terlalu abstrak, kurangnya contoh contoh kongkret dan latihan, kurangnya siswa memahami konsep dasar mata pelajaran dan kurangnya memberi kesempatan berfikir kepada siswa pada waktu bertanya jawab. Penyebab rendahnya tingkat penguasaan materi tersebut menurut pandangan penulis adalah kurangnya penguasaan guru terhadap strategi pembelajaran berkaitan dengan penyajian materi pelajaran pada siswa. Selain ketidaktepatan strategi pembelajaran yang digunakan faktor motivasi siswa untuk belajar juga menjadi salah satu sebab ketidak berhasilan pembelajaran. Faktor motivasi belajar yang tidak muncul dari siswa juga disebabkan karena faktor ketidaktepatan strategi pembelajaran yang diterapkan guru. Apabila guru dapat menggunakan strategi pembelajaran dengan baik akan dapat menarik minat dan motivasi siswa untuk belajar. Sehingga aktivitas dan hasil belajar akan meningkat, (Diah, 2004) 
Berkaitan dengan keterbatasan guru dalam menerapkan strategi pembelajaran yang efektif dalam meningkatkan hasil belajar siswa terhadap faktor-faktor yang mempengaruhi keseimbangan ekoistem pada mata pelajaran IPA, maka penulis mencoba untuk mengadakan penelitian tindakan kelas. Strategi pembelajaran yang peneliti pilih untuk menuntaskan masalah tersebut di atas adalah penerapan metode bermain peran.

\section{Metode}

Jenis penelitian yang digunakan dalam kesempatan ini adalah penelitian tindakan kelas. Alasan menggunakan penelitian tindakan kelas untuk menyelesaikan permasalahan pembelajaran yang penulis alami adalah karena keampuhan penelitian ini dalam menyelesaikan permasalahan terkait dengan permasalahan yang bersifat kelasikal dalam dunia pendidikan. Model penelitian tindakan kelas merupakan rangkaian kegiatan yang diuraikan pada masing-masing siklus seperti di bawah ini dimana tiap siklus meliputi beberapa tahap yaitu : merencanakan, melaksanakan dan refleksi. Untuk lebih jelasnya,tentang prosedur pelaksanaan tindakan dapat diilustrasikan pada diagram berikut:

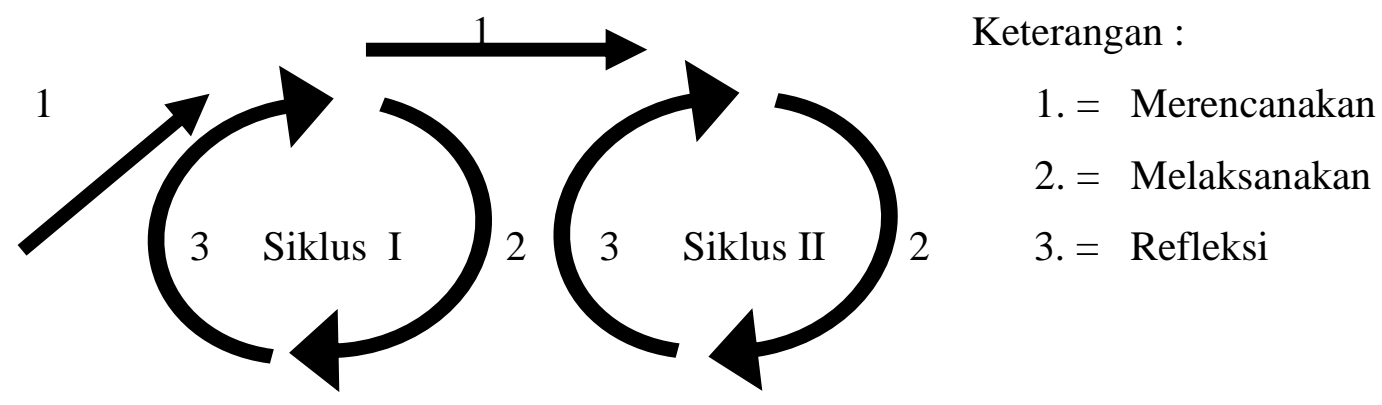

Gambar 1 Bagan Siklus PTK

\section{Subyek Penelitian}

Dalam pelaksanaan program penelitian tindakan kelas saat ini guru mengambil lokasi di tempat guru mengajar, yaitu di SDN 1 Seraya Barat yang terletak di Banjar Dinas Bungkulan, Desa Seraya Barat, Kecamatan Karangasem. Kemampuan rata-rata orang tua siswa pendukung sekolah secara ekonomi tergolong merata pada tingkatan berkecukupan. Mata pencaharian masyarakat pendukung adalah sebagai petani nelaya, pedagang, buruh, pegawai swasta dan PNS/TNI/POLRI. SDN 1 Seraya Barat pada tahun ajaran 2019/2020 memiliki VI kelas. Guru yang memegang Kelas VI mengasuh anak didik sebanyak 27 orang dengan karakteristik anak yang bervariasi sesuai dengan karakter dan keunikan. Pelaksanaan kegiatan tersebut guru laksanakan sesuai dengan 
rancangan jadwal mata pelajaran. Sehingga siswa tidak merasa terbebani dengan adanya kegiatan penelitian tersebut. Adapun jadwal pelaksanaan yang telah guru rancang sesudah melalui koordinasi dengan Kepala Sekolah SDN 1 Seraya Barat untuk mendapatkan izin pelaksanaan.

\section{Instrumen Pengumpulan Data}

Adapun instrumen pengumpulan data yang digunakan pada penelitian ini adalah lembar soal, lembar pengamatan oleh teman sejawat, rubrik pengamatan saat kegiatan lomba, blangko pengamatan aktivitas dan LKS. Lembar pengamatan oleh teman sejawat adalah untuk mengamati tingkat aktivitas siswa saat kegiatan pembelajaran. Rubrik pengamatan adalah untuk acuan pengamatan untuk pengisian blanko instrumen aktivitas. Soal-soal untuk mengetahui tingkat pemahaman siswa terhadap materi pembelajaran.

\section{Metode Pengolahan Data}

Metode pengolahan data pada penelitian ini bermula dari pengamatan terhadap lembar karya siswa berupa soal buatan siswa yang diskoring dan diinput pada tabel daftar skor pengamatan siswa di atas. Setiap item uraian kreteria mempunya kemungkinan skor antara 1 - 3 dengan katagori seperti dijelaskan pada tabel rubrik pengamatan di atas. Skor masing-masing siswa kemudian dijumlahkan di kolom jumlah skor. Kolom konversi nilai berguna untuk mengkonversi jumlah skor menjadi nilai skala ratusan untuk memudahkan memahami tingkat aktivitas siswa. Pengolahan berikutnya adalah merata-ratakan nilai konversi tersebut yang selanjutnya bermanfaat untuk mengetahui perkembangan tingkat aktivitas belajar dari satu siklus ke siklus berikutnya. Pengolahan data hasil belajar siswa berdasarkan atas soal yang diberikan di awal dan di akhir. Akumulasi nilai awal dan akhir dijadikan sebagai acuan dalam mengetahui keberhasilan belajar baik siklus I dan siklus II. Pengolahan dari skor menjadi nilai skala seratus untuk memudahkan dalam memahami peningkatan hasil belajar yang telah diperoleh.

\section{Hasil Dan Pembahasan}

\section{Deskripsi Siklus I}

a. Pertemuan I

Pelaksanaan penelitian tindakan kelas siklus I dilaksanakan pada tanggal 8 Oktober 2019 yang diawali dengan pengarahan dari guru, persiapan dan lain lain-lainnya yang dilanjukan dengan kegiatan awal dan kegiatan inti seperti tertuang dalam RPP. 
1) Guru menanyakan persiapan siswa yang sudah disampaikan sebelumnya, yaitu membentuk 4 kelompok kecil yang nanti secara bergiliran menjelaskan di depan kelas satu contoh gambar tumbuhan yang sudah dipersiapkan guru

2) Masing - masing kelompok diberikan sebuah gambar tumbuhan yang dibelakangnya dituliskan proofil tentang tumbuhan tersebut.

3) Guru memberikan kesempatan masing-masing kelompok mempelajari materi gambar tersebut selama 5 menit.

4) Masing-masing kelompok tampil di depan kelas untuk mebawakan materi gambar yang didapatkannya.

5) Salah seorang dari kelompok tersebut menjelaskan gambar yang dibawanya.

6) Selama mebacakan, kelompok lain ikut mencermati apa yang di baca tersebut.

7) Dengan arahan guru kelompok lain diberi kesempatan mengajukan pertanyaan kepada kelompok yang tampil

8) Kegiatan tersebut diulang kepada kelompok yang lain.

9) Guru dan siswa menyimpulkan hasil kegiatan pembelajaran

Selama proses pembelajaran teman sejawat mengadakan kegiatan observasi terhadap proses pembelajaran. Selanjutnya kegiatan pembelajaran dlanjutkan ke siklus I pertemuan II. Beberapa unsur atau aspek yang diobsevasi adalah keaktivan mengajukan pertanyaan, keaktifan mengungkapkan pendapat, ketepatan pertanyaan yang diajukan dan kerjasama kelompok. Berikut adalah kegiatan pembelajaran siklus I pertemuan II.

b. Pertemuan II

1) Guru menanyakan persiapan siswa yang sudah disampaikan sebelumnya, yaitu mempelajari materi sebelumnya

2) Guru dan siswa dalam kelompok secara bergiliran bertanya jawab tentang kepunahan dan alasan mereka mendekati kepunahan.

3) Guru dan siswa mendiskusikan beberapa usaha yang dapat dilakukan untuk mencegah kepunahan hewan hewan tersebut

4) Guru menyimpulakan hasil kegiatan

\section{Deskripsi Siklus II}

Pelaksanaan penelitian tindakan kelas siklus II dilaksanakan pada tanggal 15 Oktober 2019, yang diawali dengan pengarahan dari guru, persiapan dan lain lain-lainnya yang dilanjukan dengan kegiatan awal dan kegiatan inti seperti tertuang dalam RPP SIklus II. 
a. Pertemuan I

1) Guru menanyakan persiapan siswa yang sudah disampaikan sebelumnya, yaitu membentuk 4 kelompok kecil yang nanti secara bergiliran menjelaskan di depan kelas satu contoh gambar tumbuhan yang sudah dipersiapkan guru

2) Masing - masing kelompok diberikan sebuah gambar tumbuhan yang dibelakangnya dituliskan profil tentang tumbuhan tersebut.

3) Guru memberikan kesempatan masing-masing kelompok mempelajari materi gambar tersebut selama 5 menit.

4) Masing-masing kelompok tampil di depan kelas untuk mebawakan materi gambar yang didapatkannya.

5) Salah seorang dari kelompok tersebut menjelaskan gambar yang dibawanya.

6) Selama mebacakan, kelompok lain ikut mencermati apa yang di baca tersebut.

7) Dengan arahan guru kelompok lain diberi kesempatan mengajukan pertanyaan kepada kelompok yang tampil

8) Kegiatan tersebut diulang kepada kelompok yang lain.

9) Guru dan siswa menyimpulkan hasil kegiatan pembelajaran

Selama proses pembelajaran teman sejawat mengadakan kegiatan observasi terhadap proses pembelajaran. Selanjutnya kegiatan pembelajaran dlanjutkan ke siklus II pertemuan II. Beberapa unsur atau aspek yang diobsevasi adalah keaktivan mengajukan pertanyaan, keaktifan mengungkapkan pendapat, ketepatan pertanyaan yang diajukan dan kerjasama kelompok. Berikut adalah kegiatan pembelajaran siklus II pertemuan II.

b. Pertemuan II

1) Guru menanyakan persiapan siswa yang sudah disampaikan sebelumnya, yaitu mempelajari naskah drama yang sudah dibagikan oleh guru sebelumnya

2) Siswa mengelompokkan diri menjadi 4 kelompok, masing masing kelompok menamakan kelompok mereka dengan nama hewan yang paling mereka sukai.

3) Masing-masing membagi peran di antara anggota pada kelompok tersebut, ada yang sebagai Gajah, Orang utan sumatra, cendrawasih dan komodo.

4) Masing masing pembawa peran mempelajari naskah drama yang sudah dipersiapkan guru

5) Setelah semuanya siap, dengan cara undian masing-masing kelompok secara bergiliran membawakan naskah drama tersebut di depan kelas. (isi naskah drama terlampir) 
6) Setelah kegiatan berakhir siswa masing masing kelompok berdiskusi dan menjawab pertanyaan guru tentang, nama-nama hewan yang mendekati kepunahan dan alasan mereka mendekati kepunahan.

7) Guru dan siswa mendiskusikan beberapa usaha yang dapat dilakukan untuk mencegah kepunahan hewan hewan tersebut

8) Guru menyimpulakan hasil kegiatan

\section{Pembahasan Siklus I}

a. Aktivitas Belajar

Aktivitas belajar siklus I merupakan proses pembelajaran awal pada tahapan siklus I yang terdiri dari 2 kali pertemuan. Dimana peneliti yang dibantu oleh teman sejawat melakukan observasi berdasarkan rubrik kreteria yang sudah ditetapkan. Perolehan data menunjukkan bahwa rata-rata aktivitas siswa adalah 73,46 dengan tingkat ketuntasan 66,67\%. Hasil tersebut masih berada di bawah ketentuan yang telah ditetapkan seperti diuraikan pada indikator kinerja pada bab 3 di atas. Dimana proses pembelajaran dalam penelitian ini dapat dihentikan jika telah mencapai rata-rata perolehan 68 dengan tingkat ketuntasan $85 \%$.

b. Hasil Belajar

Setelah tahapan siklus I pertemuan ke 2 maka diadakan evaluasi belajar. Hal ini dilakukan untuk mengukur sejauh mana efektifitas belajar telah dilaksanakan dalam rangka meningkatkan hasil belajar siswa. Hasil belajar siswa yang diukur menggunakan lembar soal evaluasi baik pre tes dan pos tes. Berdasarkan data yang diperoleh didapatkan gambaran bahwa capaian hasil belajar telah mencapai rata-rata daya serap 69,55\% dengan ketuntasan $62,96 \%$ yang masih berada di bawah standar yang telah ditetapkan.

\section{Pembahasan Siklus II}

a. Aktivitas Belajar

Aktivitas belajar siklus II merupakan proses pembelajaran lanjutan untuk memperbaiki dan melengkapi pelaksanaan siklus I. Pada tahapan siklus II terdiri dari 2 kali pertemuan. Dimana peneliti yang dibantu oleh teman sejawat melakukan observasi berdasarkan rubrik kreteria yang sudah ditetapkan seperti yang telah di bahas pada bab 3 di atas. Perolehan data menunjukkan bahwa rata-rata aktivitas siswa adalah 84,57 dengan tingkat ketuntasan $85,19 \%$. Hasil tersebut sudah melewati ketentuan yang telah 
ditetapkan seperti diuraikan pada indikator kinerja pada bab 3 di atas. Dimana proses pembelajaran dalam penelitian ini dapat dihentikan jika telah mencapai rata-rata perolehan 68 dengan tingkat ketuntasan $85 \%$.

b. Hasil Belajar

Setelah tahapan siklus II pertemuan ke 2 maka diadakan evaluasi belajar. Hal ini dilakukan untuk mengukur sejauh mana efektifitas belajar telah dilaksanakan dalam rangka meningkatkan hasil belajar siswa. Hasil belajar siswa yang diukur menggunakan lembar soal evaluasi baik pre tes dan pos tes. Berdasarkan data yang diperoleh didapatkan gambaran bahwa capaian hasil belajar telah mencapai rata-rata daya serap $85,80 \%$ dengan ketuntasan $88,89 \%$ yang sudah melampaui standar yang telah ditetapkan. Dari gambaran di atas memperlihatkan telah terjadi peningkatan aktivitas belajar dan hasil belajar. Secara umum telah mampu melampaui indikator kinerja yang telah ditetapkan seperti yang dijelaskan pada indikator kinera pada bab 3 di atas. Berikut adalah gambaran visual tentang peningkatan aktivitas dan hasil belajar seperti gambar grafik di bawah ini.
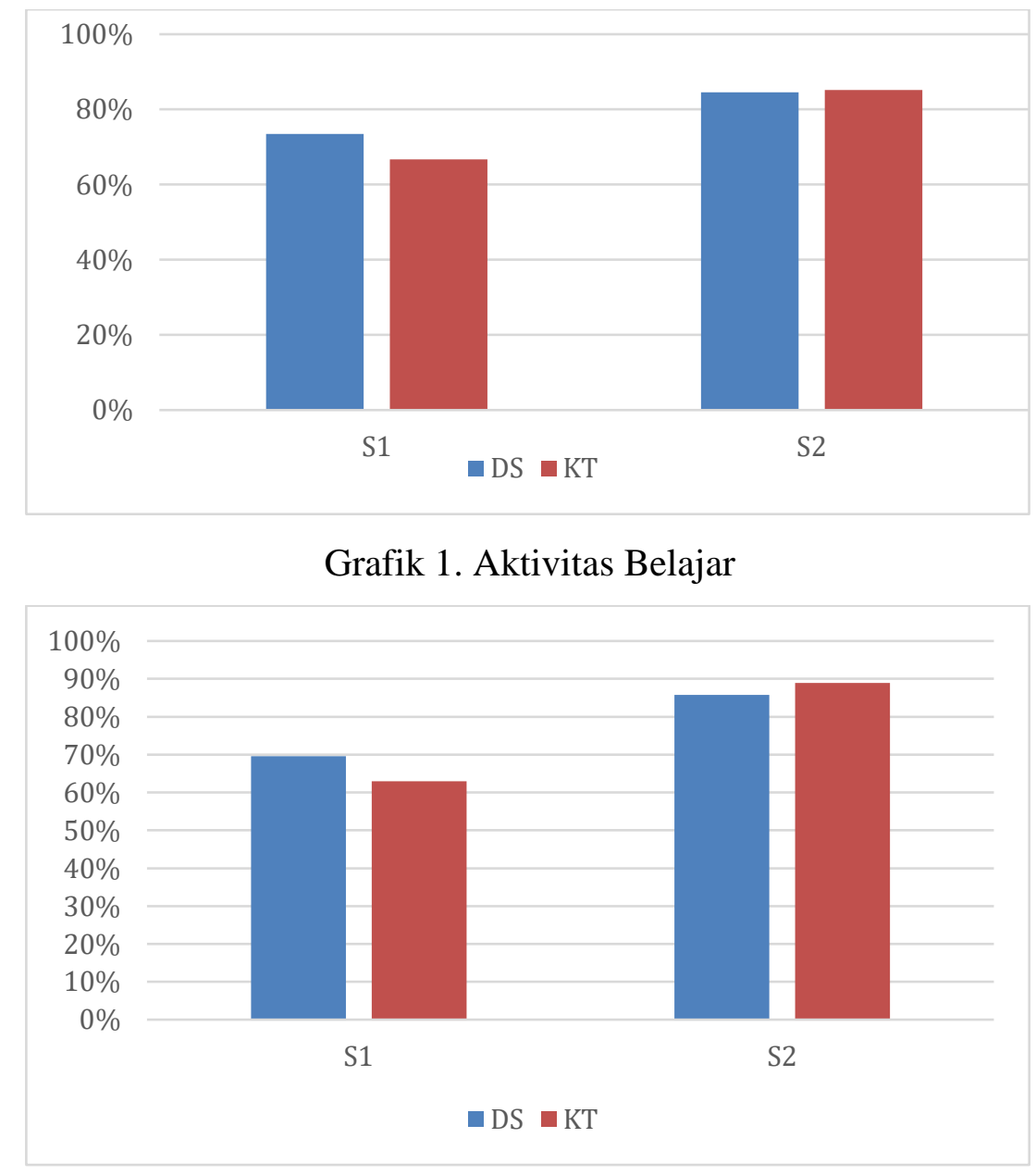

Grafik 2. Hasil Belajar Siswa 


\section{Kesimpulan}

Berdasarkan deskripsi dan pembahasan maka penelitian tindakan kelas ini dapat disimpulkan sebagai berikut 1) Penerapan metode bermain peran dapat meningkatkan aktivitas belajar mata pelajaran IPA pada siswa Semester I Kelas VI SDN 1 Seraya Barat dengan rata-rata peningkatan dari 73,46 pada siklus I menjadi 84,57 pada siklus II dan peningkatan ketuntasan sebesar $66,67 \%$ pada siklus I menjadi $85,19 \%$ pada siklus II yang berada di atas standar yang ditetapkan 2) Penerapan metode bermain peran dapat meningkatkan hasil belajar mata pelajaran IPA pada siswa Kelas VI SDN 1 Seraya Barat Semester I dengan rata-rata peningkatan dari 69,55 pada siklus I menjadi 85,80 pada siklus II dan peningkatan ketuntasan sebesar 62,96\% pada siklus I menjadi 88,98 \% pada siklus II yang berada di atas standar yang ditetapkan.

\section{Daftar Pustaka}

Abbas. (2004). Proses Belajar Mengajar. Bandung: PT. Bumi Aksara.

Agung, A.A Gede. (1999). Metodelogi Penelitian Pendidikan. Singaraja :STKIP

Anton, M, Mulyono. (2001). Aktivitas Belajar. Bandung. Yrama

Arifin, Zainul. (2005). Dasar-dasar Manajemen Bank Syariah. Pustaka Alvabet:Jakarta. Depdiknas, (2005). Peraturan Pemerintah Republik Indonesia Nomor 19 Tahun 2005 Tentang Standar Nasional Pendidikan, Jakarta: Depdiknas

Djamarah, dkk. (2000). Psikologi Belajar. Banjarmasin : Rineka Cipta

Djamarah, dkk. (2002). Strategi Belajar Mengajar. Jakarta : Rhineka Chipta

Dyah Arifiyanti. (2014). Peningkatan Minat Belajar Siswa Melalui StrategiPembelajaran Inquiring Minds Want To Know Pada Mata Pelajaran IPA Kelas IV SDN Majenang 1 Tahun 2013/2014

Hamalik, Oemar. (2001). Proses Belajar Mengajar. Jakarta : Bumi Aksara.

Hamalik, Oemar. (1995). Kurikulum dan Pembelajaran. Jakarta: Bumi Aksara

Iksanudin, (2012). Penerapan Metode Bermain Peran Untuk Meningkatkan Prestasi Belajar Operasi Bilangan Bulat Mata Pelajaran Matematika Kelas V MI Maarif 01 Layansari 2011-2012. Skripsi Thesis, Perpustakaan Uin Sunan Kalijaga. http://digilib.uin-suka.ac.id/10099/

Karso. (2000). Pendidikan IPA I, Jakarta: Universitas Terbuka.

Leo Sutrisno, Hery Kresnadi dan kartono. (2008). Pengembangan Pembelajaran IPA SD.

Dirjen Pendidikan Tinggi Depdiknas. Jakarta 
Purnomo, Agus. (2018). Pembelajaran Kontekstual Berbasis Lapangan Yang Konstruktivisme Untuk Membangun Pengetahuan Peserta Didik. Malang : State University Of Malang

Semiawan, C. (2002). Belajar dan Pembelajaran Dalam Taraf Usia Dini, Jakarta, Prehallindo.

Silberman, Mel et. al (1996). Akctive Learning: 101 Strategies to Teach Any Subject. Terjemahan Sarjuli, et.al. 101 Strategi Pembelajaran Aktive. Yogyakarta: Pustaka Insan Madani

Slamet Suyanto, dkk. (2011). Lembar Kerja Siswa. Makalah. Yogyakarta: FMIPA UNY.

Slamet. (2003). Belajar dan Faktor-Faktor yang Mempengaruhinya, Cet. IV, Jakarta: Rieneka Cipta.

Sudjana, Nana dan Ahmad Rivai. (2006) Media Pengajaran. Bandung : Sinar Baru Algesindo

Suyono dan Hariyanto. (2014). Belajar dan Pembelajaran. Bandung: Remaja Rosdakarya.

Ubaidillah, M. (2018). Metode Field Trip Untuk Meningkatkan Kemampuan Pemahaman Konsep Fisika Dan Mengakses Keterampilan Proses Sains. Jurnal Pendidikan Sains (JPS), 6(2).

Wardani, Wihardit dan Nasution. (2004). Penelitian Tindakan Kelas, Jakarta: Universitas Terbuka. 